\title{
Profile of interleukin-22 in gut mucosal health and disease
}

This article was published in the following Dove Press journal:

International Journal of Interferon, Cytokine and Mediator Research

II April 2016

Number of times this article has been viewed

\section{Russell B Foxall' \\ Susana M Fernandes ${ }^{1,2}$ \\ Ana E Sousa' \\ 'Instituto de Medicina Molecular, Faculdade de Medicina, Universidade de Lisboa, Lisboa, Portugal; ${ }^{2}$ Hospital Santa Maria, Centro Hospitalar Lisboa Norte, Lisboa, Portugal}

\begin{abstract}
Interleukin-22 (IL-22) is produced by both innate and adaptive immune cells and specifically targets nonhematopoietic cells; this provides a unique mechanism linking host immunity to mucosal homeostasis and led to its establishment as a key player in the maintenance of barrier integrity at mucosal sites particularly in the gut. Our aim is to provide an overview of the role of this cytokine in maintaining gut mucosal homeostasis in the steady state and in disease. IL-22 has two main functions in healthy states: to help shape the gut microbial flora via the induction of mucins and antimicrobial peptides and to maintain barrier integrity through the induction of epithelial cell proliferation and/or survival. Given the risk of malignancy related to uncontrolled cell growth per se, it is not surprising that the expression of this cytokine is tightly regulated by a complex interactive signaling network. This consists of a combination of cytokines and various environmental signals that can be derived directly from the diet and/or the gut microbiota. A role for IL-22 in response to gut infection has been reported. Here, we will focus specifically on how reduced levels of this cytokine can exacerbate disease pathology, as in the case of human immunodeficiency virus infection. We will also review its association with inflammatory bowel disease, where its net contribution likely reflects the balance between its pro- and anti-inflammatory functions, as well as its role in malignancy, specifically colorectal cancer. Finally, we will briefly discuss the potential pros and cons of targeting IL-22 in these, and other, clinical situations.
\end{abstract}

Keywords: IL-22, gut, inflammation, infection, cancer

\section{Introduction and aim}

Since its discovery 15 years ago, interleukin-22 (IL-22) has emerged as a key player in the maintenance of mucosal homeostasis and preservation of barrier sites. ${ }^{1}$ Conversely, it has been linked to a number of pathologies, including autoimmune disorders ${ }^{2}$ and cancer. ${ }^{3}$

The aim of this review is to outline how IL-22 helps maintain mucosal homeostasis in steady-state conditions and during pathological insults, and, in turn, how this may, in the context of its dysregulated expression, result in pathology. As the role of IL-22 in a range of organs and tissues has recently been reviewed in depth, ${ }^{4}$ we will focus here on its multifaceted role in human gut mucosa, in health and during infection, and the ways in which it may contribute to important gut pathologies such as inflammatory bowel disease (IBD) and colorectal cancer (CRC).

\section{IL-22: a brief introduction}

IL-22 was first described by Dumoutier et $\mathrm{al}^{5}$ as "IL-10-related T-cell-derived inducible factor (IL-TIF).” Originally considered an IL-10 cytokine family member, ${ }^{5}$ it has
Correspondence: Russell B Foxall Ana E Sousa's Research Unit, Instituto Medicina, Universidade de Lisboa, Av. Prof. Egas Moniz, 1649-028 Lisboa, Portugal Tel +35I 217999525

Fax +351217999525

Email rfoxall@medicina.ulisboa.pt
International Journal of Interferon, Cytokine and Mediator Research 2016:8 I-II

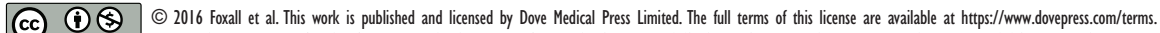

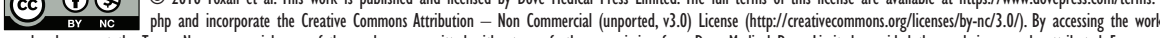
you hereby accept the Terms. Non-commercial uses of the work are permitted without any further permission from Dove Medical Press Limited, provided the work is properly attributed. For permission for commercial use of this work, please see paragraphs 4.2 and 5 of our Terms (https://www.doveperess.com/terms.php).
Dovepress

http://dx.doi.org/|0.2147/IIICMR. 564856 
recently been reassigned to the IL-20 cytokine subfamily, ${ }^{6}$ with whose other members it shares considerable structural homology. ${ }^{6,7}$ The $I L-22$ gene is located on chromosome 12q15 in humans and chromosome 10 in mice. ${ }^{5}$ Human IL-22 is expressed as a 179-amino-acid protein, sharing reasonably high homology with its murine counterpart (79\%) as well as $25 \%$ homology with IL- $10{ }^{8}$ The active, monomeric form of IL-22 is secreted as a 146-amino-acid protein ${ }^{9,10}$ consisting of six helices, four of which form a bundle characteristic of Class II cytokines, and a small N-terminal helix. ${ }^{?}$

\section{Where is IL-22 produced?}

Constitutive expression of IL-22 was initially observed in the thymus and brain, ${ }^{5}$ with induced expression subsequently being observed in many other tissues such as the gut, liver, skin, lung, pancreas, and spleen. ${ }^{11}$ For the purposes of this review, we will concentrate on IL-22 in the context of the gut mucosa.

\section{Which cells produce IL-22?}

Apart from a couple of reports of nonlymphoid cells producing IL-22 under specific conditions, ${ }^{12,13}$ the available human and murine data indicate that cells of lymphoid origin represent the primary source of this cytokine, with both innate and adaptive immune cells able to produce IL-22 (Table 1). ${ }^{5,14-24}$ In terms of innate immune cell populations, an IL-22 producing innate lymphoid cell (ILC) subset, recently reclassified as group 3 innate lymphoid cells (ILC3), ${ }^{25}$ is extremely relevant, ${ }^{22,26}$ with those expressing the natural killer cell cytotoxicity receptor $\mathrm{Nkp} 44+$ being of particular importance in the context of human gut mucosa. ${ }^{21,27}$

It is important to note that despite some phenotypic differences, the various cell types that produce IL-22 also share some common features. In particular, they all appear to require the expression of the transcription factor ROR $\gamma \mathrm{t}$. This has been directly linked to the development of ILC $3 \mathrm{~s},{ }^{22,28}$ with its expression likely regulating IL-22 production by other lymphoid cell subsets in the periphery. ${ }^{4}$

Table I Lymphoid cell populations able to produce IL-22

\begin{tabular}{ll}
\hline Lymphoid cells & References \\
\hline CD4+ $\alpha \beta$ T-cells (ThI, Th I7, Th22) & $5,14,15$ \\
CD8+ $\alpha \beta$ T-cells (Tc22) & 16 \\
$\gamma \delta$ T-cells & 17 \\
NKT cells & 18 \\
NK cells & 19,20 \\
ILC3s & $14,21,22$ \\
Mast cells & 23 \\
Neutrophils & 24 \\
\hline
\end{tabular}

Abbreviations: Th, T-helper; Tc, T-cytotoxic; NKT, natural killer T-cell; ILC3s, Class 3 innate lymphoid cells; IL-22, interleukin-22.

\section{The IL-22 receptor}

The heterodimeric receptor of IL-22 (IL-22R) belongs to the Type 2 cytokine receptor family and consists of the IL$22 \mathrm{R} 1$ chain and the $\beta$-chain of the IL-10 receptor (IL-10R $\beta$, Figure 1). ${ }^{29}$ The former's intracellular domain is associated with Tyk2 and the latter's with Jak1 (Figure 1).

\section{Expression pattern}

IL-22R is almost exclusively expressed on nonhematopoietic cell populations in various tissues, including the gut mucosa, ${ }^{1}$ skin, ${ }^{30}$ pancreas, ${ }^{31}$ lung, ${ }^{32}$ and liver. ${ }^{33}$

\section{Downstream effects of IL-22/IL-22R signaling}

Binding of IL-22 to its receptor leads to phosphorylation of the associated kinases, and consequently members of the STAT family, primarily STAT3, as well as activation of the MAP kinase and p38 pathways (Figure 1). ${ }^{34}$

In general, signaling via IL-22R is associated with promotion of cell survival and/or proliferation both of which likely contribute to its pivotal role in tissue regeneration, a process observed in various models of tissue damage. ${ }^{33,35}$ It also mediates certain tissue-specific activities such as induction of antimicrobial peptides in the gut ${ }^{21}$ and skin. ${ }^{30}$ Data also suggest that, under certain circumstances, IL-22 can act as a proinflammatory cytokine. ${ }^{36}$ The unique combination of the cell subsets that account for the majority of IL-22 production (immune cells) and those which express its receptor (nonhematopoietic cells) endows this cytokine with its distinctive ability to link these two compartments and act as a key player in maintaining homeostasis at mucosal and/or barrier sites.

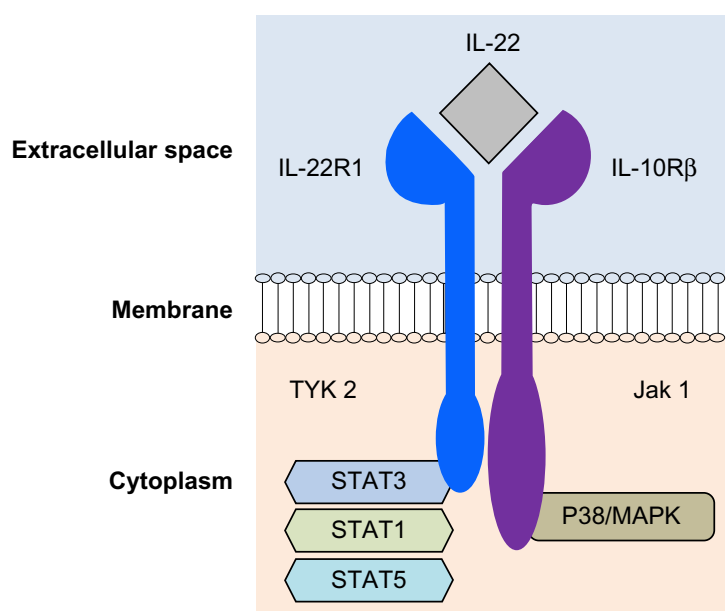

Figure I IL-22 receptor structure.

Notes: Illustration of the heterodimeric IL-22 receptor (IL-22R), consisting of IL$22 \mathrm{RI}$ (blue) and IL-IOR $\beta$ (purple) chains and the associated signaling molecules. Abbreviation: IL-22, interleukin-22; MAPK, mitogen-associated protein kinase. 


\section{Role of IL-22 in host defense}

Various studies, in both mice and humans, indicate that IL-22 can play a role in immunity to infection caused by various classes of pathogens, including bacteria, ${ }^{37-40}$ viruses, ${ }^{41-44}$ and parasites $^{45,46}$ (Table 2). It is important to note that in many cases, the data regarding the impact of IL-22 in these contexts are contradictory, with reports suggesting that it can help limit and/or exacerbate pathology. ${ }^{39,40}$ The overall outcome in any given pathological context likely reflects the balance struck between the ability of IL-22 to mediate tissue repair and its proinflammatory capacity. The local cytokine environment in which IL-22 is being produced ${ }^{36,47}$ may also influence whether its effects are ultimately beneficial or deleterious.

Of note, IL-22 has been shown to induce the production of acute-phase proteins by hepatocytes. ${ }^{5,48}$ More recently, a systemic role of IL-22 in the context of infection has been reported, with it being shown to induce $\mathrm{C} 3$ production and augment C3-mediated phagocytosis in a murine model of disseminated Clostridium difficile infection. ${ }^{49}$ Thus, it is possible that this cytokine may help mediate protection against infection beyond its normal tissue-specific functions.

\section{IL-22 and the gut}

Production of IL-22 has been observed throughout the gastrointestinal (GI) tract. Here, we will focus on its role in the context of the gut mucosa, particularly that of the colon, as this represents an ideal model to illustrate the dual nature of this cytokine.

\section{The gut mucosa}

The gut mucosa represents the largest body surface in contact with the external environment, functioning as a selective portal that allows the passage of nutrients while keeping foreign organisms at bay. An active interplay occurs between

Table 2 IL-22 involvement in the response to pathogens

\begin{tabular}{lll}
\hline Pathogen targeted & $\begin{array}{l}\text { Site of action in } \\
\text { infected host }\end{array}$ & Reference(s) \\
\hline $\begin{array}{lll}\text { Bacteria } \\
\text { Gram-negative species }\end{array}$ & Lung & 37 \\
Citrobacter rodentium & Gut & 38 \\
Mycobacterium tuberculosis & Lung & 39,40 \\
Viruses & & \\
Hepatitis B & Liver & 42 \\
Hepatitis C & Liver & 41 \\
Rotavirus & Gut & 43,44 \\
Parasites & & 45 \\
Malaria & Liver & 46 \\
Leishmaniasis & Skin & \\
\hline
\end{tabular}

Abbreviation: IL-22, interleukin-22. the gut microbiota and the cellular components of the gut (epithelial, stromal, and immune cells). This interaction shapes both ecosystems in a continuous process starting after birth, which ultimately helps determine the overall health of the host. ${ }^{50,51}$

\section{IL-22 and gut homeostasis}

IL-22 plays an important role in gut homeostasis. A key contribution is through the maintenance of barrier integrity, with ILC3-produced IL-22 being of particular importance. ${ }^{1,21}$ IL-22 serves several functions in the gut (Figure 2). It regulates epithelial cell proliferation and survival ${ }^{52}$ and plays an important role in wound healing. ${ }^{53}$ It induces the production of a wide range of proteins required for normal gut epithelial function, including antimicrobial peptides and members of the REG, defensin, and S100 protein families. ${ }^{21,54-56}$ Furthermore, recent data suggest that IL-22 may play a role in the maintenance and or/repair of epithelial tight junctions. ${ }^{57-59}$

\section{Regulation of IL-22 production in the gut}

There are several lymphocyte subsets of particular relevance in terms of IL-22 production in the gut: $\alpha \beta$ CD4+ T-cells (in particular the Th17 and Th22 subsets) and $Y \delta$ T-cells that patrol the lamina propria and the gut resident ILC3s.

Given the ability of IL-22 to promote tissue proliferation and/or survival, coupled with its potential to act as a proinflammatory cytokine, it is not surprising that IL-22

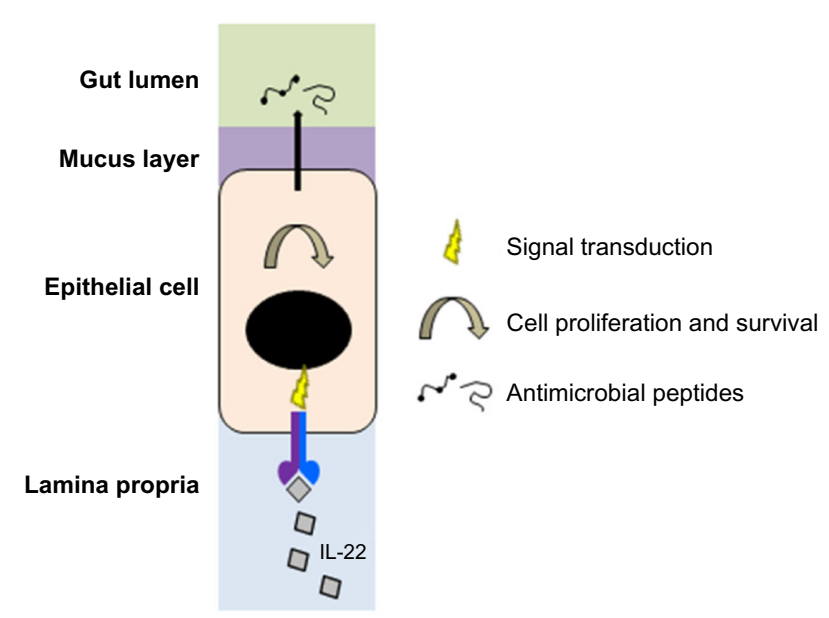

Figure 2 Effects of IL-22/IL-22R signaling in gut epithelial cells.

Notes: The binding of IL-22 to its cognate receptor (IL-22R) activates a signaling cascade that can ultimately result in the induction of cell proliferation and enhancement of cell survival through induction of antiapoptotic programs, as well as in the production of antimicrobial peptides.

Abbreviation: IL-22, interleukin-22. 
production by these cells is tightly regulated via a complex interactive process involving cytokines, environmental factors, and soluble receptors (Figure 3).

\section{Cytokines}

Cytokines can either positively or negatively regulate IL-22 production. Several cytokines produced by a variety of cell types have been shown to drive production of IL-22, either by directly inducing its expression or by promoting the differentiation and/or survival of IL-22-producing populations. Of these, IL-23, a member of the IL-12 cytokine family, plays a key role, being able to induce expression of this cytokine in a number of immune cells. ${ }^{4}$ Dendritic cells (DCs) are a major source of IL-23, particularly in the gut, with murine $\mathrm{CD} 103^{+60}$ and $\mathrm{CX} 3 \mathrm{CR} 1^{+61} \mathrm{DC}$ subsets producing it in response to pathogens and environmental cues. In humans, monocyte-derived dendritic cells have been shown to produce IL-23 on exposure to commensal Gram-negative bacteria.$^{62}$ Furthermore, IL-23 production by monocyte-derived dendritic cells was augmented by CD40L/CD40-mediated DC-T-cell interactions. ${ }^{63}$ Proinflammatory cytokines, such as IL- $1 \beta$ and IL-6, can also induce IL-22 production. The former is particularly relevant in the gut, where it can directly induce IL-22 production by ILCs, ${ }^{64}$ and indirectly through its capacity to promote the survival and proliferation of IL-22-producing ILCs. ${ }^{65}$ IL-6 can also induce IL-22 production by a variety of cell types, including $\gamma \delta$ T-cells ${ }^{17}$ and ILC3s. ${ }^{66}$ IL-21 drives the differentiation of human naive CD8+T-cells into Tc22 cells. ${ }^{16}$ However, regarding ILC3s, it seems to function by regulating the interaction between the aryl-hydrocarbon receptor (AhR) and the IL-22 promoter, and thus may help integrate IL-22 inductive signals from cytokines and environmental factors. Recent data also suggest a reciprocal relationship between IL-18 and IL-22, with the former able to regulate IL-22 expression in the ileum and the latter inducing IL-18 during Toxoplasma gondii infection. ${ }^{67}$

Conversely, several cytokines have been implicated in the suppression of IL-22 production, although the underlying mechanisms differ. Thus, IL-25 may indirectly target IL-22 production by suppressing the production of IL-23. ${ }^{68}$ On the other hand, Transforming growth factor (TGF) $\beta$ appears to function more directly: although linked with Th17 differentiation, ${ }^{69}$ it can suppress IL-22 production $^{70}$ in a c-maf-dependent manner. ${ }^{71}$ IL-27, a member of the IL-12 cytokine family that is known to have anti-inflammatory properties $^{72}$ also directly blocks IL-22 production by human T-cells, in an suppressor of cytokine signaling 1 (SOCS1)dependent manner. ${ }^{73}$

\section{Environmental factors}

Pathogen-associated molecular patterns, a broad class of molecules including both structural components, such as bacterial

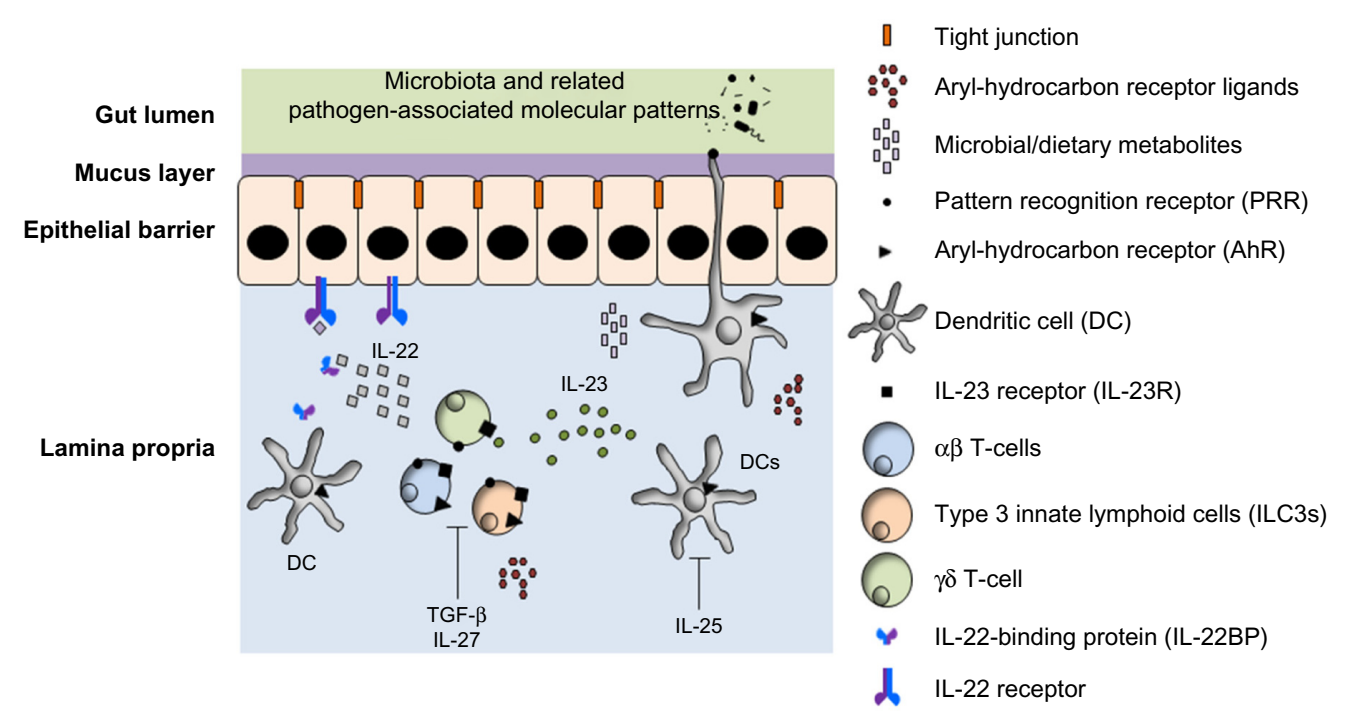

Figure 3 IL-22 production and regulation in the gut mucosa.

Notes: IL-22 is produced by both innate (ILC3s and $\gamma \delta$ T-cells) and adaptive ( $\alpha \beta$ CD4+ ThI7 and/or Th22 as well as CD8+ Tcl7 and/or Tc22 subsets) immune cells in the gut. This occurs in response to a variety of signals, including cytokines; most importantly, IL-23 produced by DCs in response to environmental factors, including AhR ligands, dietary-derived compounds, and bacterially derived products featuring PAMPs recognized by PRR. In addition, environmental factors can also regulate IL-22 production by directly targeting IL-22-producing cell populations. Cytokines can also suppress IL-22 production directly, by antagonizing its production (TGF- $\beta$ and IL-27), or indirectly, by suppressing IL-23 production (IL-25). IL-22-binding protein (IL-22BP), a soluble IL-22 receptor, binds IL-22 and prevents it from signaling its target cell populations.

Abbreviations: AhR, aryl-hydrocarbon receptor; DC, dendritic cell; IL, interleukin; PAMP, pathogen-associated molecular pattern; PRR, pattern recognition receptor; TGF- $\beta$, Transforming growth factor beta; IL-22, interleukin-22. 
lipopolysaccharide, and nucleic acids, are recognized by several classes of invariant pattern recognition receptors, such as the Toll-like receptor family. ${ }^{74}$ They have been shown to trigger IL-22 production both indirectly by inducing IL-23 production by $\mathrm{DCs}^{60}$ and directly via TLR 2 expressed on IL22-producing immune cells such as ILC $3 \mathrm{~s}^{75}$ and $\gamma \delta$ T-cells. ${ }^{76}$ In the gut, pattern recognition receptors are expressed on the basal surface of the epithelial cells, ${ }^{77}$ ensuring these cells only respond to pathogen-associated molecular patterns when the epithelial barrier is disrupted. ${ }^{78}$ The capacity of gut DCs to sample the gut lumen ${ }^{79}$ and the two-way conversation between the microbiota and ILC $3 \mathrm{~s}^{80}$ also help regulate IL-22 production, further ensuring it is restricted to situations where epithelial damage and/or shifts in microbiota populations (dysbiosis) has occurred.

Various food-derived compounds can regulate IL-22 production. Vitamin D can modulate DC cytokine production and indirectly promote the differentiation of IL-22-producing cells. ${ }^{81}$ Gut microbiota also plays an important role in this respect, either indirectly through the release of metabolites ${ }^{82}$ or directly via inducing retinoic acid production (a metabolite of vitamin A) by $\mathrm{DCs},{ }^{83}$ which can, in turn, induce IL-22 production by ILC $3 \mathrm{~s}$ and $y \delta$ T-cells. ${ }^{84}$ Conversely, retinoic acid can negatively regulate IL-22 production via the induction of IL-22-binding protein (IL-22BP) by DCs ${ }^{85}$ and IL-25 production by enterocyte. ${ }^{86}$

\section{AhR}

AhR is a key regulator of IL-22 production in the gut. It is a cytoplasmic receptor with several immune-regulatory functions. ${ }^{87}$ Although initially shown to bind environmental toxins such as Dioxin, a range of endogenously derived ligands have subsequently been identified, originating from both dietary sources and the microbiota. ${ }^{88}$

Not only is AhR able to drive IL-22 production by ILC $3 \mathrm{~s},{ }^{89}$ it also regulates their development. ${ }^{90}$ This is particularly important given the key role ILC3s play in controlling intestinal immunity and inflammation. ${ }^{89}$ AhR has also been linked to IL-22 production by several other cell types, such as $\mathrm{V} \gamma 2$ subset of $\gamma \delta \mathrm{T}$-cells, ${ }^{76} \mathrm{Th} 22$ cells, ${ }^{15}$ and neutrophils. ${ }^{24}$ It is important to note that the AhR is also expressed in DCs and macrophages, ${ }^{11}$ and thus, its activation in these cells may be able to indirectly regulate IL-22 induction.

\section{IL-22BP}

This is a soluble form of the IL22R1 receptor chain, encoded by a separate gene, ${ }^{92}$ rather than generated by alternative splicing. IL-22BP expression has been observed in various tissues, including the gut. ${ }^{93}$ DCs are the major, but not the sole producer, of this soluble receptor. ${ }^{85,93}$

The binding footprint of IL-22BP on IL-22 overlaps that of the IL22R1, allowing it to directly interfere with the binding of IL-22 to its membrane-bound receptor. ${ }^{94}$ The inhibitory effect of IL-22BP is enhanced by the fact that the affinity of its interaction with IL-22 is $\sim 1,000$-fold higher than that of IL-22 and the membrane bound form of IL-22R1. ${ }^{95}$ As discussed later, IL-22BP interaction with IL-22 may play a role in both IBD $^{96}$ and colon cancer. ${ }^{97}$

Overall, it is clear that this complex network, involving a fine balance between the microbiota, immune system, and the epithelial barrier, is vital in maintaining homeostasis in the context of the gut, with disruption of this system potentially leading to inflammation and associated pathologies.

\section{IL-22 and gut immunity}

The role of IL-22 in mediating antibacterial immunity in the context of the gut has been widely reported. In particular, it is vital in orchestrating the immune response to Citrobacter rodentium in mice, an experimental model of pathogenic Escherichia coli infection. ${ }^{38}$ IL-22 in this context seems to be initially derived from ILC3s, although its production by adaptive immune cells appears necessary in the later stages of infection to allow for effective resolution of the disease. ${ }^{38,80,98,99}$

Of note, IL-22 also helps regulate immune responses to commensal microbiota, such as those targeting segmented filamentous bacteria, ${ }^{100}$ with recent data indicating an important role of IL-23 in regulating this process. ${ }^{101,102}$

IL-22 also plays a role in the host response to viral infections in the context of the gut.

It was recently identified as a key player in the response to rotavirus infection in both mice ${ }^{43}$ and humans. ${ }^{44}$

\section{Human immunodeficiency virus- I infection and the gut: the role of IL-22}

A good example highlighting the importance of IL-22 in maintaining gut homeostasis in humans is provided by human immunodeficiency virus-1 (HIV-1) infection.

HIV-1 infection is characterized by rapid and profound depletion of CD4 T-cells from the GI mucosa, structural deterioration of the gut epithelium, and translocation of microbial products from the gut lumen into the systemic circulation. The combination of these factors is thought to contribute to chronic hyperimmune activation, ${ }^{103}$ which we and others have shown to be a hallmark of HIV infection and a major determinant of disease progression. ${ }^{104,105}$ It is also important to note that the interaction between HIV and mucosal barriers 
has important consequences not only for disease pathogenesis but also for transmission. ${ }^{106}$

HIV-1 infection appears to impact on important IL-22producing cell populations. A loss of IL-22-producing T-cells in the peripheral blood of antiretroviral therapy (ART)-naive HIV-1+ individuals has been reported. ${ }^{107,108}$ Circulating ILC3s have also been shown to be depleted in HIV-1+ individuals. ${ }^{109}$ In simian immunodeficiency virus-infected macaques, a widely used model of HIV-1 infection, depletion of ILC3s was observed in mucosal and systemic lymphoid tissues. ${ }^{110}$ Furthermore, loss of IL-22-producing cells was associated with mucosal damage in this model. ${ }^{111}$ The limited human data available suggest that mucosal IL-22 production is reduced in chronic HIV-1 infection..$^{57,112}$

No consensus has yet been reached as to whether successful ART can result in the restoration of normal gut function. ${ }^{113}$ Data suggest that disturbances in gut homeostasis persist in the context of ART..$^{57,114,115}$ We have not only shown that Th22 are depleted in colon biopsies from long-term treated individuals but also observed that the frequency of ILC3s was similar in ART-treated HIV-1 and seronegative individuals. ${ }^{116}$ This observation, coupled with an apparent lack of gut disturbances in ART-treated individuals, led us to conclude that ART allowed for ILC3 recovery, which, in turn, was sufficient to restore gut homeostasis. ${ }^{116}$

Nevertheless, long-term ART-treated HIV-1+ individuals still show persistent immune activation that is related to a variety of comorbidities, ${ }^{117}$ with continued alterations at the level of the gut, such as persistence of microbial dysbiosis. ${ }^{118}$ Recent data suggest that initiation of ART during the early phase of HIV-1 infection may be more efficient in restoring/ preserving normal gut function. ${ }^{112}$

HIV-1 has also been shown to directly disrupt epithelial tight junctions in an infection-independent manner. ${ }^{119} \mathrm{Kim}$ et $\mathrm{al}^{57}$ demonstrated that IL-22 was able to abrogate this effect, further emphasizing the importance of IL-22's capacity to interact with epithelia in helping maintain gut homeostasis in the context of HIV infection.

Overall, HIV-1 appears to directly impact on key IL-22producing lymphocyte populations, with evidence suggesting that ART may allow for the recovery of some of them, at least in the context of long-term treatment, and thus enable some degree of recovery of gut homeostasis.

\section{IL-22 and IBD}

IBD encompasses a range of chronic relapsing disorders of the GI tract that are primarily characterized by excessive inflammation. Among them, Crohn's disease (CD) and ulcerative colitis (UC) are of particular clinical relevance in the developed world. ${ }^{120}$ In general, IBD can be viewed as a disruption of the complex interactions between the gut immune system and its resident microbial flora. Under normal conditions, this allows for tolerance to food-derived antigens as well as to those of commensal bacteria beneficial to the host, while still permitting the generation of immune responses to invading pathogenic species and/or pathobionts. The loss of this fine balance can result in inflammation that, rather than resolving, persists, eventually resulting in a state of chronic intestinal inflammation that typifies IBD.

As recently reviewed by Geremia et al, ${ }^{121}$ IBD can involve both the innate and adaptive arms of host immunity. Furthermore, cytokines, including IL-22, play a critical role in its pathogenesis. $^{122}$

However, the role of IL-22 in IBD is complex. Evidence supports a role of IL-22 in driving IBD, through its ability to function as a proinflammatory cytokine. ${ }^{123-125}$ Certainly, IL-23, a potent inducer of IL-22 production, ${ }^{4}$ has a key role, ${ }^{126}$ with an expansion of IL-23-responsive ILCs observed in the context of IBD. ${ }^{127}$ It is also important to note that Th17 cells can produce both IL-22 and IL-17, with the latter also being associated with the IBD pathogenesis. ${ }^{126}$ Moreover, a recent study demonstrated that IFN- $\gamma /$ IL-17-coproducing CD4+ T-cells specifically enriched in the inflamed mucosal tissue of patients with IBD also showed high expression levels of IL-22. ${ }^{128}$

However, data from mouse models support an important protective role of IL-22 in IBD. ${ }^{35,129}$ In humans, a loss of the Th22 subset has been reported in the colon of patients with $\mathrm{UC},{ }^{130}$ whereas IL-22 production by ILCs has been seen to be impaired in inflamed tissue of patients with $\mathrm{CD} ;{ }^{58}$ increased production of IL-22BP, a negative regulator of IL-22 function, has also been observed in human IBD. ${ }^{96}$ A protective role of IL-22 in human IBD; in this case, UC is further supported by the report of amelioration of symptoms in an individual who deliberately infected themselves with Trichuris trichiura, resulting in an expansion of IL-22producing CD4+ T-cells. ${ }^{131}$

Thus, it seems that IL-22 can also be beneficial in the context of IBD, which is perhaps not surprising given its capacity to directly interact with gut epithelia and mediate tissue repair in this context. ${ }^{53}$ However, the suggestion that IL-22 represents a potential therapeutic candidate for $\mathrm{IBD}^{129}$ has to be balanced against the evidence supporting a role of this cytokine in IBD pathogenesis. 


\section{IL-22 and cancer}

Just as for IBD, IL-22's role in cancer is complex. Recent data from human studies have linked IL-22 to cancers as diverse as multiple myeloma ${ }^{132}$ and glioblastoma. ${ }^{133}$ Here, we will focus on IL-22's role in CRC. The fact that chronic intestinal inflammation is a widely accepted risk factor for CRC development ${ }^{134}$ and that, as discussed earlier, IL-22 is upregulated in the context of IBD provides strong circumstantial evidence of a role of this cytokine in CRC. Furthermore, genetic polymorphisms in the $I L-22$ gene have been identified as a colon cancer risk factor. ${ }^{135} \mathrm{~A}$ complex network of cytokines, including IL-22, underlies CRC. ${ }^{3}$ Murine studies provide evidence for a role of IL-22 in CRC. ${ }^{136}$ Data from IL-22BP- - - mice indicating increased intestinal tumorigenesis also support a role of augmented IL-22 levels in driving tumor development at this site. ${ }^{97}$ In humans, Jiang et al ${ }^{137}$ reported an accumulation of tumor-infiltrating lymphocytes that are able to produce IL-22, with IL-22-mediated STAT3 induction promoting tumor growth and metastasis in an in vivo system. ${ }^{137}$ Similarly, Th22 cells were found to accumulate in CRC tissue, with subsequent in vitro and in vivo studies again implicating the IL-22/STAT3 signaling axis in cancer cell proliferation and survival. ${ }^{138} \mathrm{~A}$ recent report suggested that IL-22 enhances stemness in the context of CRC by upregulating core stem cell genes such as Nanog. This, in turn, enhanced tumorigenecity, with an association between increased expression levels of these genes and poor patient prognosis also observed. ${ }^{139}$ This may be a particularly important role of IL-22 in CRC, given this cytokine's role in maintaining intestinal stem cell viability in mice. ${ }^{140}$

Increased serum IL-22 has been associated with resistance to chemotherapy in patients with CRC, ${ }^{141}$ with an ability to enhance in vitro chemoresistence in CRC cell lines also being reported. ${ }^{142}$

This subject has been recently reviewed in depth. ${ }^{143}$ According to the author's proposed model, IL-22 could exert anticancer effects through its ability to promote pathogen clearance, mediate short-term inflammation, and help both resolve this and promote tissue repair. However, its continued expression could drive tissue dysplasia and, subsequently, tumor formation. Several of its functions could then augment tumor growth, by aiding angiogenesis, tissue invasion, and ultimately metastasis.

\section{Conclusion}

IL-22 production and signaling require strict regulation in the gut mucosa to guarantee an adequate balance of its beneficial and potentially deleterious properties, and hence maintain mucosal homeostasis and repair.

In steady-state conditions, it is required to help maintain epithelial cells, which provide the barrier between the host and the external environment. The interactions between a range of lymphoid cells, the microbiota, and other environmental signals ensure the fine tuning of IL-22 levels, such that they maintain barrier function without provoking overt inflammation (Figure 3). It is also interesting to note that the persistent disruption of gut homeostasis observed in HIV infection ${ }^{103}$ is linked to a loss of IL-22-producing subsets, ${ }^{57,112}$ further highlighting the importance of this cytokine in maintaining a healthy gut environment.

However, it is easy to imagine that IL-22 could have deleterious effects in the gut, particularly given its ability to enhance epithelial cell survival and/or proliferation. ${ }^{52,53}$ Thus, circumstances where IL-22 production is dysregulated and/or prolonged could lead to epithelial hyperplasia and ultimately cancer. ${ }^{143}$

As IL-22 has been linked to a variety of pathologies outside of the gut, ${ }^{2}$ particularly inflammatory skin disorders such as psoriasis and atopic dermatitis, ${ }^{144}$ and it has been suggested that it could represent a viable therapeutic target. However, whether its expression would require augmenting or reducing will likely be dictated by the particular clinical situation. ${ }^{11}$

Thus, blocking IL-22 may be of benefit in cancer or autoimmunity, whereas enhancing its expression in the context of certain gut infections or IBD may be beneficial; the latter is supported by data indicating that local delivery of the $I L-22$ gene to inflamed colonic tissue results in the amelioration of inflammation in a Th2-mediated mouse colitis model. ${ }^{145}$ However, it would be vital to ensure that modulation of IL-22 be restricted to the target tissue to avoid damaging "off-target" side effects.

\section{Disclosure}

The authors report no conflicts of interest in this work.

\section{References}

1. Sonnenberg GF, Fouser LA, Artis D. Border patrol: regulation of immunity, inflammation and tissue homeostasis at barrier surfaces by IL-22 Nat Immunol. 2011;12(5):383-390.

2. Azizi G, Yazdani R, Mirshafiey A. Th22 cells in autoimmunity: a review of current knowledge. Eur Ann Allergy Clin Immunol. 2015;47(4):108-117.

3. West NR, McCuaig S, Franchini F, Powrie F. Emerging cytokine networks in colorectal cancer. Nat Rev Immunol. 2015;15(10):615-629.

4. Dudakov JA, Hanash AM, van den Brink MR. Interleukin-22: immunobiology and pathology. Annu Rev Immunol. 2015;33:747-785. 
5. Dumoutier L, Louahed J, Renauld JC. Cloning and characterization of IL-10-related T cell-derived inducible factor (IL-TIF), a novel cytokine structurally related to IL-10 and inducible by IL-9. J Immunol. 2000;164(4):1814-1819.

6. Rutz S, Wang X, Ouyang W. The IL-20 subfamily of cytokines from host defence to tissue homeostasis. Nat Rev Immunol. 2014; 14(12):783-795.

7. Trivella DB, Ferreira-Júnior JR, Dumoutier L, Renauld JC, Polikarpov I. Structure and function of interleukin-22 and other members of the interleukin-10 family. Cell Mol Life Sci. 2010;67(17):2909-2935.

8. Dumoutier L, Van Roost E, Colau D, Renauld JC. Human interleukin-10related T cell-derived inducible factor: molecular cloning and functional characterization as an hepatocyte-stimulating factor. Proc Natl Acad Sci U S A. 2000;97(18):10144-10149.

9. Xie MH, Aggarwal S, Ho WH, et al. Interleukin (IL)-22, a novel human cytokine that signals through the interferon receptor-related proteins CRF2-4 and IL-22R. J Biol Chem. 2000;275(40):31335-31339.

10. Nagem RA, Colau D, Dumoutier L, Renauld JC, Ogata C, Polikarpov I. Crystal structure of recombinant human interleukin-22. Structure. 2002;10(8):1051-1062.

11. Sabat R, Ouyang W, Wolk K. Therapeutic opportunities of the IL-22IL-22R1 system. Nat Rev Drug Discov. 2014;13(1):21-38.

12. Hansson M, Silverpil E, Lindén A, Glader P. Interleukin-22 produced by alveolar macrophages during activation of the innate immune response. Inflamm Res. 2013;62(6):561-569.

13. Ikeuchi H, Kuroiwa T, Hiramatsu N, et al. Expression of interleukin-22 in rheumatoid arthritis: potential role as a proinflammatory cytokine. Arthritis Rheum. 2005;52(4):1037-1046.

14. Wolk K, Kunz S, Asadullah K, Sabat R. Cutting edge: immune cells as sources and targets of the IL-10 family members? J Immunol. 2002;168(11):5397-5402.

15. Trifari S, Kaplan CD, Tran EH, Crellin NK, Spits H. Identification of a human helper $\mathrm{T}$ cell population that has abundant production of interleukin 22 and is distinct from $\mathrm{T}(\mathrm{H})-17, \mathrm{~T}(\mathrm{H}) 1$ and $\mathrm{T}(\mathrm{H}) 2$ cells. Nat Immunol. 2009;10(8):864-871.

16. Liu Y, Yang B, Ma J, et al. Interleukin-21 induces the differentiation of human Tc22 cells via phosphorylation of signal transducers and activators of transcription. Immunology. 2011;132(4):540-548.

17. Ness-Schwickerath KJ, Morita CT. Regulation and function of IL-17A- and IL-22-producing $\gamma \delta \mathrm{T}$ cells. Cell Mol Life Sci. 2011;68(14):2371-2390.

18. Moreira-Teixeira L, Resende M, Coffre M, et al. Proinflammatory environment dictates the IL-17-producing capacity of human invariant NKT cells. J Immunol. 2011;186(10):5758-5765.

19. Kumar P, Thakar MS, Ouyang W, Malarkannan S. IL-22 from conventional NK cells is epithelial regenerative and inflammation protective during influenza infection. Mucosal Immunol. 2013;6(1):69-82.

20. Guo X, Qiu J, Tu T, et al. Induction of innate lymphoid cell-derived interleukin-22 by the transcription factor STAT3 mediates protection against intestinal infection. Immunity. 2014;40(1):25-39.

21. Cella M, Fuchs A, Vermi W, et al. A human natural killer cell subset provides an innate source of IL-22 for mucosal immunity. Nature. 2009;457(7230):722-725.

22. Montaldo E, Juelke K, Romagnani C. Group 3 innate lymphoid cells (ILC3s): origin, differentiation, and plasticity in humans and mice. Eur J Immunol. 2015;45(8):2171-2182.

23. Mashiko S, Bouguermouh S, Rubio M, Baba N, Bissonnette R, Sarfati M. Human mast cells are major IL-22 producers in patients with psoriasis and atopic dermatitis. J Allergy Clin Immunol. 2015;136(2): 351.e1-359.e1.

24. Zindl CL, Lai JF, Lee YK, et al. IL-22-producing neutrophils contribute to antimicrobial defense and restitution of colonic epithelial integrity during colitis. Proc Natl Acad Sci U S A. 2013;110(31):12768-12773.

25. Spits H, Artis D, Colonna M, et al. Innate lymphoid cells - a proposal for uniform nomenclature. Nat Rev Immunol. 2013;13(2):145-149.

26. Hazenberg MD, Spits H. Human innate lymphoid cells. Blood. 2014;124(5):700-709.
27. Fuchs A, Colonna M. Innate lymphoid cells in homeostasis, infection, chronic inflammation and tumors of the gastrointestinal tract. Curr Opin Gastroenterol. 2013;29(6):581-587.

28. Montaldo E, Teixeira-Alves LG, Glatzer T, et al. Human RORgammat(+)CD34(+) cells are lineage-specified progenitors of group 3 RORgammat(+) innate lymphoid cells. Immunity. 2014; 41(6):988-1000.

29. Kotenko SV, Izotova LS, Mirochnitchenko OV, et al. Identification of the functional interleukin-22 (IL-22) receptor complex: the IL-10R2 chain (IL-10Rbeta) is a common chain of both the IL-10 and IL-22 (IL-10-related T cell-derived inducible factor, IL-TIF) receptor complexes. J Biol Chem. 2001;276(4):2725-2732.

30. Wolk K, Witte E, Wallace E, et al. IL-22 regulates the expression of genes responsible for antimicrobial defense, cellular differentiation, and mobility in keratinocytes: a potential role in psoriasis. Eur J Immunol. 2006;36(5):1309-1323.

31. Aggarwal S, Xie MH, Maruoka M, Foster J, Gurney AL. Acinar cells of the pancreas are a target of interleukin-22. J Interferon Cytokine Res. 2001;21(12):1047-1053.

32. Pociask DA, Scheller EV, Mandalapu S, et al. IL-22 is essential for lung epithelial repair following influenza infection. Am J Pathol. 2013;182(4):1286-1296.

33. Radaeva S, Sun R, Pan HN, Hong F, Gao B. Interleukin 22 (IL-22) plays a protective role in T cell-mediated murine hepatitis: IL-22 is a survival factor for hepatocytes via STAT3 activation. Hepatology. 2004;39(5):1332-1342.

34. Lejeune D, Dumoutier L, Constantinescu S, Kruijer W, Schuringa JJ, Renauld JC. Interleukin-22 (IL-22) activates the JAK/STAT, ERK, JNK, and p38 MAP kinase pathways in a rat hepatoma cell line. Pathways that are shared with and distinct from IL-10. J Biol Chem. 2002;277(37):33676-33682.

35. Zenewicz LA, Yancopoulos GD, Valenzuela DM, Murphy AJ, Stevens S, Flavell RA. Innate and adaptive interleukin-22 protects mice from inflammatory bowel disease. Immunity. 2008;29(6): 947-957.

36. Muhl H. Pro-inflammatory signaling by IL-10 and IL-22: bad habit stirred up by interferons? Front Immunol. 2013;4:18.

37. Aujla SJ, Chan YR, Zheng M, et al. IL-22 mediates mucosal host defense against Gram-negative bacterial pneumonia. Nat Med. 2008;14(3):275-281.

38. Zheng Y, Valdez PA, Danilenko DM, et al. Interleukin-22 mediates early host defense against attaching and effacing bacterial pathogens. Nat Med. 2008;14(3):282-289.

39. Dhiman R, Periasamy S, Barnes PF, et al. NK1.1+ cells and IL-22 regulate vaccine-induced protective immunity against challenge with Mycobacterium tuberculosis. J Immunol. 2012;189(2):897-905.

40. Matthews K, Wilkinson KA, Kalsdorf B, et al. Predominance of interleukin-22 over interleukin-17 at the site of disease in human tuberculosis. Tuberculosis (Edinb). 2011;91(6):587-593.

41. Gao W, Fan YC, Zhang JY, Zheng MH. Emerging role of interleukin 22 in hepatitis B virus infection: a double-edged sword. J Clin Transl Hepatol. 2013;1(2):103-108.

42. Dambacher J, Beigel F, Zitzmann K, et al. The role of interleukin-22 in hepatitis C virus infection. Cytokine. 2008;41(3):209-216.

43. Zhang B, Chassaing B, Shi Z, et al. Viral infection. Prevention and cure of rotavirus infection via TLR5/NLRC4-mediated production of IL-22 and IL-18. Science. 2014;346(6211):861-865.

44. Hernández PP, Mahlakõiv T, Yang I, et al. Interferon-lambda and interleukin 22 act synergistically for the induction of interferonstimulated genes and control of rotavirus infection. Nat Immunol. 2015;16(7):698-707.

45. Mastelic B, do Rosario AP, Veldhoen M, et al. IL-22 protects against liver pathology and lethality of an experimental blood-stage malaria infection. Front Immunol. 2012;3:85.

46. Gimblet C, Loesche MA, Carvalho L, et al. IL-22 protects against tissue damage during cutaneous leishmaniasis. PLoS One. 2015;10(8):e0134698. 
47. Sonnenberg GF, Nair MG, Kirn TJ, Zaph C, Fouser LA, Artis D. Pathological versus protective functions of IL-22 in airway inflammation are regulated by IL-17A. J Exp Med. 2010;207(6):1293-1305.

48. Liang SC, Nickerson-Nutter C, Pittman DD, et al. IL-22 induces an acute-phase response. J Immunol. 2010;185(9):5531-5538.

49. Hasegawa M, Yada S, Liu MZ, et al. Interleukin-22 regulates the complement system to promote resistance against pathobionts after pathogen-induced intestinal damage. Immunity. 2014;41(4): 620-632.

50. Round JL, Mazmanian SK. The gut microbiota shapes intestinal immune responses during health and disease. Nat Rev Immunol. 2009;9(5):313-323.

51. Yu LC, Wang JT, Wei SC, Ni YH. Host-microbial interactions and regulation of intestinal epithelial barrier function: From physiology to pathology. World J Gastrointest Pathophysiol. 2012;3(1):27-43.

52. Nagalakshmi ML, Rascle A, Zurawski S, Menon S, de Waal Malefyt R. Interleukin-22 activates STAT3 and induces IL-10 by colon epithelial cells. Int Immunopharmacol. 2004;4(5):679-691.

53. Pickert G, Neufert C, Leppkes M, et al. STAT3 links IL-22 signaling in intestinal epithelial cells to mucosal wound healing. $J$ Exp Med. 2009;206(7):1465-1472.

54. Liang SC, Tan XY, Luxenberg DP, et al. Interleukin (IL)-22 and IL-17 are coexpressed by Th17 cells and cooperatively enhance expression of antimicrobial peptides. J Exp Med. 2006;203(10):2271-2279.

55. Sonnenberg GF, Monticelli LA, Alenghat T, et al. Innate lymphoid cells promote anatomical containment of lymphoid-resident commensal bacteria. Science. 2012;336(6086):1321-1325.

56. Sanos SL, Vonarbourg C, Mortha A, Diefenbach A. Control of epithelial cell function by interleukin-22-producing RORgammat+ innate lymphoid cells. Immunology. 2011;132(4):453-465.

57. Kim CJ, Nazli A, Rojas OL, et al. A role for mucosal IL-22 production and Th22 cells in HIV-associated mucosal immunopathogenesis. Mucosal Immunol. 2012;5(6):670-680.

58. Mizuno S, Mikami Y, Kamada N, et al. Cross-talk between RORgammat+ innate lymphoid cells and intestinal macrophages induces mucosal IL-22 production in Crohn's disease. Inflamm Bowel Dis. 2014;20(8):1426-1434.

59. Tominaga A, Konishi Y, Taguchi T, et al. Autonomous cure of damaged human intestinal epithelial cells by TLR2 and TLR4-dependent production of IL-22 in response to Spirulina polysaccharides. Int Immunopharmacol. 2013;17(4):1009-1019.

60. Kinnebrew MA, Buffie CG, Diehl GE, et al. Interleukin 23 production by intestinal CD103(+)CD11b(+) dendritic cells in response to bacterial flagellin enhances mucosal innate immune defense. Immunity. 2012;36(2):276-287.

61. Niess JH, Adler G. Enteric flora expands gut lamina propria CX3CR1+ dendritic cells supporting inflammatory immune responses under normal and inflammatory conditions. J Immunol. 2010;184(4) 2026-2037.

62. Smits HH, van Beelen AJ, Hessle C, et al. Commensal Gramnegative bacteria prime human dendritic cells for enhanced IL-23 and IL-27 expression and enhanced Th1 development. Eur J Immunol. 2004;34(5):1371-1380.

63. Sender LY, Gibbert K, Suezer Y, Radeke HH, Kalinke U, Waibler Z. CD40 ligand-triggered human dendritic cells mount interleukin-23 responses that are further enhanced by danger signals. Mol Immunol. 2010;47(6):1255-1261.

64. Lee Y, Kumagai Y, Jang MS, et al. Intestinal Lin- c-Kit+ NKp46CD4- population strongly produces IL-22 upon IL-1beta stimulation. J Immunol. 2013;190(10):5296-5305.

65. Hughes T, Becknell B, Freud AG, et al. Interleukin-1beta selectively expands and sustains interleukin-22+ immature human natural killer cells in secondary lymphoid tissue. Immunity. 2010;32(6):803-814.

66. Powell N, Lo JW, Biancheri P, et al. Interleukin 6 increases production of cytokines by colonic innate lymphoid cells in mice and patients with chronic intestinal inflammation. Gastroenterology. 2015;149(2): 456.e15-467.e15.
67. Muñoz M, Eidenschenk C, Ota N, et al. Interleukin-22 induces interleukin-18 expression from epithelial cells during intestinal infection. Immunity. 2015;42(2):321-331.

68. Zaph C, Du Y, Saenz SA, et al. Commensal-dependent expression of IL-25 regulates the IL-23-IL-17 axis in the intestine. $J$ Exp Med. 2008;205(10):2191-2198.

69. Veldhoen M, Hocking RJ, Atkins CJ, Locksley RM, Stockinger B. TGFbeta in the context of an inflammatory cytokine milieu supports de novo differentiation of IL-17-producing T cells. Immunity. 2006;24(2):179-189.

70. Volpe E, Touzot M, Servant N, et al. Multiparametric analysis of cytokine-driven human Th17 differentiation reveals a differential regulation of IL-17 and IL-22 production. Blood. 2009;114(17):3610-3614.

71. Rutz S, Noubade R, Eidenschenk C, et al. Transcription factor c-Maf mediates the TGF-beta-dependent suppression of IL-22 production in T(H)17 cells. Nat Immunol. 2011;12(12):1238-1245.

72. Kastelein RA, Hunter CA, Cua DJ. Discovery and biology of IL-23 and IL-27: related but functionally distinct regulators of inflammation. Annu Rev Immunol. 2007;25:221-242.

73. Wang H, Li Z, Yang B, Yu S, Wu C. IL-27 suppresses the production of IL-22 in human CD4(+) T cells by inducing the expression of SOCS1. Immunol Lett. 2013;152(2):96-103.

74. Kumar H, Kawai T, Akira S. Pathogen recognition by the innate immune system. Int Rev Immunol. 2011;30(1):16-34.

75. Crellin NK, Trifari S, Kaplan CD, Satoh-Takayama N, Di Santo JP, Spits H. Regulation of cytokine secretion in human CD127(+) LTi-like innate lymphoid cells by Toll-like receptor 2. Immunity. 2010;33(5):752-764.

76. Martin B, Hirota K, Cua DJ, Stockinger B, Veldhoen M. Interleukin-17producing gammadelta $\mathrm{T}$ cells selectively expand in response to pathogen products and environmental signals. Immunity. 2009;31(2):321-330.

77. Furrie E, Macfarlane S, Thomson G, Macfarlane GT. Toll-like receptors-2, -3 and -4 expression patterns on human colon and their regulation by mucosal-associated bacteria. Immunology. 2005;115(4):565-574.

78. Sierro F, Dubois B, Coste A, Kaiserlian D, Kraehenbuhl JP, Sirard JC. Flagellin stimulation of intestinal epithelial cells triggers CCL20mediated migration of dendritic cells. Proc Natl Acad Sci U S A. 2001;98(24):13722-13727.

79. Niess JH, Brand S, Gu X, et al. CX3CR1-mediated dendritic cell access to the intestinal lumen and bacterial clearance. Science. 2005;307(5707):254-258.

80. Satoh-Takayama N, Vosshenrich CA, Lesjean-Pottier S, et al. Microbial flora drives interleukin 22 production in intestinal NKp46+ cells that provide innate mucosal immune defense. Immunity. 2008;29(6):958-970.

81. Sommer A, Fabri M. Vitamin D regulates cytokine patterns secreted by dendritic cells to promote differentiation of IL-22-producing T cells. PLoS One. 2015;10(6):e0130395.

82. Berndt BE, Zhang M, Owyang SY, et al. Butyrate increases IL-23 production by stimulated dendritic cells. Am J Physiol Gastrointest Liver Physiol. 2012;303(12):G1384-G1392.

83. Konieczna P, Ferstl R, Ziegler M, et al. Immunomodulation by Bifidobacterium infantis 35624 in the murine lamina propria requires retinoic acid-dependent and independent mechanisms. PLoS One. 2013;8(5):e62617.

84. Mielke LA, Jones SA, Raverdeau M, et al. Retinoic acid expression associates with enhanced IL-22 production by gammadelta T cells and innate lymphoid cells and attenuation of intestinal inflammation. J Exp Med. 2013;210(6):1117-1124.

85. Martin JC, Bériou G, Heslan M, et al. Interleukin-22 binding protein (IL-22BP) is constitutively expressed by a subset of conventional dendritic cells and is strongly induced by retinoic acid. Mucosal Immunol. 2014;7(1):101-113.

86. Sawa S, Lochner M, Satoh-Takayama N, et al. RORgammat+ innate lymphoid cells regulate intestinal homeostasis by integrating negative signals from the symbiotic microbiota. Nat Immunol. 2011; 12(4):320-326. 
87. Stockinger B, Di Meglio P, Gialitakis M, Duarte JH. The aryl hydrocarbon receptor: multitasking in the immune system. Annu Rev Immunol. 2014;32:403-432.

88. Denison MS, Nagy SR. Activation of the aryl hydrocarbon receptor by structurally diverse exogenous and endogenous chemicals. Annu Rev Pharmacol Toxicol. 2003;43:309-334.

89. Qiu J, Heller JJ, Guo X, et al. The aryl hydrocarbon receptor regulates gut immunity through modulation of innate lymphoid cells. Immunity. 2012;36(1):92-104.

90. Lee JS, Cella M, McDonald KG, et al. AHR drives the development of gut ILC22 cells and postnatal lymphoid tissues via pathways dependent on and independent of notch. Nat Immunol. 2012;13(2):144-151.

91. Nguyen NT, Hanieh H, Nakahama T, Kishimoto T. The roles of aryl hydrocarbon receptor in immune responses. Int Immunol. 2013;25(6):335-343.

92. Kotenko SV, Izotova LS, Mirochnitchenko OV, et al. Identification, cloning, and characterization of a novel soluble receptor that binds IL-22 and neutralizes its activity. J Immunol. 2001;166(12): 7096-7103.

93. Xu W, Presnell SR, Parrish-Novak J, et al. A soluble class II cytokine receptor, IL-22RA2, is a naturally occurring IL-22 antagonist. Proc Natl Acad Sci U S A. 2001;98(17):9511-9516.

94. Wu PW, Li J, Kodangattil SR, et al. IL-22R, IL-10R2, and IL-22BP binding sites are topologically juxtaposed on adjacent and overlapping surfaces of IL-22. J Mol Biol. 2008;382(5):1168-1183.

95. Jones BC, Logsdon NJ, Walter MR. Structure of IL-22 bound to its high-affinity IL-22R1 chain. Structure. 2008;16(9):1333-1344.

96. Martin JC, Beriou G, Heslan M, et al. IL-22BP is produced by eosinophils in human gut and blocks IL-22 protective actions during colitis. Mucosal Immunol. 2016;9(2):539-549.

97. Huber S, Gagliani N, Zenewicz LA, et al. IL-22BP is regulated by the inflammasome and modulates tumorigenesis in the intestine. Nature. 2012;491(7423):259-263.

98. Backert I, Koralov SB, Wirtz S, et al. STAT3 activation in Th17 and Th22 cells controls IL-22-mediated epithelial host defense during infectious colitis. J Immunol. 2014;193(7):3779-3791.

99. Basu R, O’Quinn DB, Silberger DJ, et al. Th22 cells are an important source of IL-22 for host protection against enteropathogenic bacteria. Immunity. 2012;37(6):1061-1075.

100. Atarashi K, Tanoue T, Ando M, et al. Th17 cell induction by adhesion of microbes to intestinal epithelial cells. Cell. 2015;163(2): 367-380.

101. Sano T, Huang W, Hall JA, et al. An IL-23R/IL-22 circuit regulates epithelial serum amyloid A to promote local effector Th17 responses. Cell. 2015;163(2):381-393.

102. Shih VF, Cox J, Kljavin NM, et al. Homeostatic IL-23 receptor signaling limits Th17 response through IL-22-mediated containment of commensal microbiota. Proc Natl Acad Sci U S A. 2014; 111(38):13942-13947.

103. Brenchley JM, Price DA, Schacker TW, et al. Microbial translocation is a cause of systemic immune activation in chronic HIV infection. Nat Med. 2006;12(12):1365-1371.

104. Sousa AE, Carneiro J, Meier-Schellersheim M, Grossman Z, Victorino RM. CD4 T cell depletion is linked directly to immune activation in the pathogenesis of HIV-1 and HIV-2 but only indirectly to the viral load. J Immunol. 2002;169(6):3400-3406.

105. Grossman Z, Meier-Schellersheim M, Sousa AE, Victorino RM, Paul WE. CD4+ T-cell depletion in HIV infection: are we closer to understanding the cause? Nat Med. 2002;8(4):319-323.

106. Burgener A, McGowan I, Klatt NR. HIV and mucosal barrier interactions: consequences for transmission and pathogenesis. Curr Opin Immunol. 2015;36:22-30.

107. Page EE, Greathead L, Metcalf R, et al. Loss of Th22 cells is associated with increased immune activation and IDO-1 activity in HIV-1 infection. J Acquir Immune Defic Syndr. 2014;67(3):227-235.

108. Guillot-Delost M, Le Gouvello S, Mesel-Lemoine M, et al. Human CD90 identifies Th17/Tc17 T cell subsets that are depleted in HIVinfected patients. J Immunol. 2012;188(3):981-991.
109. Zhang Z, Cheng L, Zhao J, et al. Plasmacytoid dendritic cells promote HIV-1-induced group 3 innate lymphoid cell depletion. J Clin Invest. 2015;125(9):3692-3703.

110. Xu H, Wang X, Lackner AA, Veazey RS. Type 3 innate lymphoid cell depletion is mediated by TLRs in lymphoid tissues of simian immunodeficiency virus-infected macaques. FASEB J. 2015;29(12): 5072-5080.

111. Klatt NR, Estes JD, Sun X, et al. Loss of mucosal CD103+ DCs and IL-17+ and IL-22+ lymphocytes is associated with mucosal damage in SIV infection. Mucosal Immunol. 2012;5(6):646-657.

112. Kok A, Hocqueloux L, Hocini H, et al. Early initiation of combined antiretroviral therapy preserves immune function in the gut of HIVinfected patients. Mucosal Immunol. 2015;8(1):127-140.

113. Costiniuk CT, Angel JB. Human immunodeficiency virus and the gastrointestinal immune system: does highly active antiretroviral therapy restore gut immunity? Mucosal Immunol. 2012;5(6): 596-604.

114. Somsouk M, Estes JD, Deleage C, et al. Gut epithelial barrier and systemic inflammation during chronic HIV infection. AIDS. 2015;29(1):43-51.

115. Chung CY, Alden SL, Funderburg NT, Fu P, Levine AD. Progressive proximal-to-distal reduction in expression of the tight junction complex in colonic epithelium of virally-suppressed HIV+ individuals. PLoS Pathog. 2014;10(6):e1004198

116. Fernandes SM, Pires AR, Ferreira C, et al. Enteric mucosa integrity in the presence of a preserved innate interleukin 22 compartment in HIV type 1-treated individuals. J Infect Dis. 2014;210(4):630-640.

117. Klatt NR, Chomont N, Douek DC, Deeks SG. Immune activation and HIV persistence: implications for curative approaches to HIV infection. Immunol Rev. 2013;254(1):326-342.

118. Dinh DM, Volpe GE, Duffalo C, et al. Intestinal microbiota, microbial translocation, and systemic inflammation in chronic HIV infection. J Infect Dis. 2015;211(1):19-27.

119. Nazli A, Chan O, Dobson-Belaire WN, et al. Exposure to HIV-1 directly impairs mucosal epithelial barrier integrity allowing microbial translocation. PLoS Pathog. 2010;6(4):e1000852.

120. Molodecky NA, Soon IS, Rabi DM, et al. Increasing incidence and prevalence of the inflammatory bowel diseases with time, based on systematic review. Gastroenterology. 2012;142(1):46-54.e42.

121. Geremia A, Biancheri P, Allan P, Corazza GR, Di Sabatino A. Innate and adaptive immunity in inflammatory bowel disease. Autoimmun Rev. 2014;13(1):3-10.

122. Neurath MF. Cytokines in inflammatory bowel disease. Nat Rev Immunol. 2014;14(5):329-342.

123. Brand S, Beigel F, Olszak T, et al. IL-22 is increased in active Crohn's disease and promotes proinflammatory gene expression and intestinal epithelial cell migration. Am J Physiol Gastrointest Liver Physiol. 2006;290(4):G827-G838.

124. Kamanaka M, Huber S, Zenewicz LA, et al. Memory/effector (CD45RB(lo)) CD4 T cells are controlled directly by IL-10 and cause IL-22-dependent intestinal pathology. J Exp Med. 2011; 208(5):1027-1040.

125. Eken A, Singh AK, Treuting PM, Oukka M. IL-23R+ innate lymphoid cells induce colitis via interleukin-22-dependent mechanism. Mucosal Immunol. 2014;7(1):143-154.

126. Cătană CS, Berindan Neagoe I, Cozma V, Magdas C, Tăbăran F, Dumitraşcu DL. Contribution of the IL-17/IL-23 axis to the pathogenesis of inflammatory bowel disease. World $J$ Gastroenterol. 2015;21(19):5823-5830.

127. Geremia A, Arancibia-Cárcamo CV, Fleming MP, et al. IL-23responsive innate lymphoid cells are increased in inflammatory bowel disease. J Exp Med. 2011;208(6):1127-1133.

128. Globig AM, Hennecke N, Martin B, et al. Comprehensive intestinal $\mathrm{T}$ helper cell profiling reveals specific accumulation of IFNgamma+IL-17+coproducing CD4+ T cells in active inflammatory bowel disease. Inflamm Bowel Dis. 2014;20(12):2321-2329.

129. LiLJ, Gong C, Zhao MH, Feng BS. Role of interleukin-22 in inflammatory bowel disease. World J Gastroenterol. 2014;20(48):18177-18188. 
130. Leung JM, Davenport M, Wolff MJ, et al. IL-22-producing CD4+ cells are depleted in actively inflamed colitis tissue. Mucosal Immunol. 2014;7(1):124-133.

131. Broadhurst MJ, Leung JM, Kashyap V, et al. IL-22+ CD4+ T cells are associated with therapeutic trichuris trichiura infection in an ulcerative colitis patient. Sci Transl Med. 2010;2(60):60ra88.

132. Di Lullo G, Marcatti M, Heltai S, et al. Th22 cells increase in poor prognosis multiple myeloma and promote tumor cell growth and survival. Oncoimmunology. 2015;4(5):e1005460.

133. Akil H, Abbaci A, Lalloué F, et al. IL22/IL-22R pathway induces cell survival in human glioblastoma cells. PLoS One. 2015;10(3): e0119872.

134. Jess T, Rungoe C, Peyrin-Biroulet L. Risk of colorectal cancer in patients with ulcerative colitis: a meta-analysis of population-based cohort studies. Clin Gastroenterol Hepatol. 2012;10(6):639-645.

135. Thompson CL, Plummer SJ, Tucker TC, Casey G, Li L. Interleukin-22 genetic polymorphisms and risk of colon cancer. Cancer Causes Control. 2010;21(8):1165-1170.

136. Kirchberger S, Royston DJ, Boulard O, et al. Innate lymphoid cells sustain colon cancer through production of interleukin-22 in a mouse model. J Exp Med. 2013;210(5):917-931.

137. Jiang R, Wang H, Deng L, et al. IL-22 is related to development of human colon cancer by activation of STAT3. BMC Cancer. 2013;13:59.

138. Huang YH, Cao YF, Jiang ZY, Zhang S, Gao F. Th22 cell accumulation is associated with colorectal cancer development. World $J$ Gastroenterol. 2015;21(14):4216-4224.
139. Kryczek I, Lin Y, Nagarsheth N, et al. IL-22(+)CD4(+) T cells promote colorectal cancer stemness via STAT3 transcription factor activation and induction of the methyltransferase DOT1L. Immunity. 2014;40(5):772-784.

140. Hanash AM, Dudakov JA, Hua G, et al. Interleukin-22 protects intestinal stem cells from immune-mediated tissue damage and regulates sensitivity to graft versus host disease. Immunity. 2012;37(2): 339-350.

141. Wu T, Cui L, Liang Z, Liu C, Liu Y, Li J. Elevated serum IL-22 levels correlate with chemoresistant condition of colorectal cancer. Clin Immunol. 2013;147(1):38-39.

142. Wu T, Wang Z, Liu Y, et al. Interleukin 22 protects colorectal cancer cells from chemotherapy by activating the STAT3 pathway and inducing autocrine expression of interleukin 8. Clin Immunol. 2014;154(2):116-126.

143. Lim C, Savan R. The role of the IL-22/IL-22R1 axis in cancer. Cytokine Growth Factor Rev. 2014;25(3):257-271.

144. Mirshafiey A, Simhag A, El Rouby NM, Azizi G. T-helper 22 cells as a new player in chronic inflammatory skin disorders. Int J Dermatol. 2015;54(8):880-888.

145. Sugimoto K, Ogawa A, Mizoguchi E, et al. IL-22 ameliorates intestinal inflammation in a mouse model of ulcerative colitis. J Clin Invest. 2008;118(2):534-544.

\section{Publish your work in this journal}

The International Journal of Interferon, Cytokine and Mediator Research is an international, peer-reviewed, open-access, online journal. The focus of the journal is to publish original research, reports, editorials, reviews and commentaries on all aspects of interferon, cytokine and mediators of inflammation from labora- tory science to therapeutic indications and clinical studies. The manuscript management system is completely online and includes a very quick and fair peer-review system, which is all easy to use. Visit http://www.dovepress.com/testimonials.php to read real quotes from published authors. 